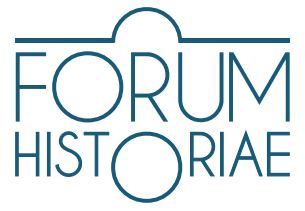

\title{
Space, Paper, Transition/ality at Bolzanova 7. The Dissolution of the Czech Samizdat Scene and the Growth of Zine Culture in the 1990s
}

\author{
Martin Tharp
}

\begin{abstract}
THARP, Martin: Space, Paper, Transition/ality at Bolzanova 7. The Dissolution of the Czech Samizdat Scene and the Growth of Zine Culture in the 1990s.

The present contribution takes a relatively unconventional angle for its investigation of the abrupt shift in Czech unofficial journalistic culture from severely repressed samizdat before November 1989 to significant social force in the first years of the subsequent decade. It takes as its locus the Prague office building at the address Bolzanova 7, a former Czech Rail property assigned to the samizdat-based independent journalistic agency Informační servis at the end of 1990. Here, in the hectic early years of uncensored publication, the rapid diversification of Czech independent periodicals witnessed the emergence of both culturally prestigious organs (the weekly magazine Respekt, the quarterly cultural journal Revolver Revue) and of attempts to reformulate a counterculture under radically different conditions - specifically the transformation of the underground information bulletin Voknoviny into the anarchist periodical A-Kontra. My interest in the present study is in examining the processes involved in this particular historical moment, as much from an analytical as well as a (necessary) descriptive aspect.
\end{abstract}

Keywords: Czech, samizdat, independent press, dissent, postsocialism, 1990s

DOI: https://doi.org/10.31577/forhist.2020.14.2.6

$\mathrm{I}^{\mathrm{n}}$ n cultural histories of the late $20^{\text {th }}$ century, particularly those that examine the world of pre-cyberspace periodicals, one question is likely to remain a vexing topic of debate. The last decade before the cyberspace revolution witnessed a rapid flourishing of independent paper-based journalism, very often closely tied to independent musical cultures, the publications that rapidly became known as "zines". Chronologically, though, the efflorescence of zine culture in the 1990s is no less remarkable for its following upon a very different form of self-publication activity: samizdat production under the state-socialist regimes of the USSR and its satellite states in Europe, prevalent throughout the post-Stalinist era up until the rapid dismantling of government censorship and the command-economy control of print technology in the 1989 - 1991 period.

The historical proximity between the two tendencies is far too strong to be ascribed to coincidence alone - yet the exact form of the connection is harder to discern. Zine culture, while definitely established long before 1989 and its subsequent ramifications, was clearly given its post-1989 impetus by the reflected moral credit of anti-communist dissidence, or more specifically the credit of cultural opposition to a state order of aesthetic policing, a brave defiance of the world 
of grey polyester suits and "estrada" musical kitsch. ${ }^{1}$ Samizdat, by contrast, essentially vanished as a political phenomenon with the ending of state control over content and production, often with its authors and publishers rapidly - in some cases, as we shall see, almost literally overnight - moving into the sphere of an official post-1989 culture.

Further adding to the difficulty is the peculiar circumstance of the historical overlap of two different forms of autonomous periodical publication. Specifically, this observation affects the emergence in the final years of Communist rule of subcultural self-created publications that more closely match Western zines than more traditionally political or intellectual samizdat. Likewise linked to popular music or sports fandom, the zines of the Communist/post-Communist regions had their own trajectory and their own history; more significantly, they represented still another manifestation of the search for an independent culture outside of either state-imposed or commercial paradigms. And, more notably, they lie outside of the established paradigms of dissent and assent, of (totalitarian) state and (democratic) civil society, pointing the way towards a public sphere without the omnipresent pressure of continual agonistic conflicts between state control and autonomous culture.

With all this in mind, the relation between zine and samizdat clearly shows, with the benefit of historical hindsight, the occurrence of a major shift, indeed a sharp discontinuity, and that the historic breakpoint of (more or less) the year of 1990 witnessed a genuine transition from one distinct social order to another. As much as this claim may sound like a banal truism, it is worth reiterating, particularly as these circumstances, here subsumed under the ugly neologism "transitionality", retreat further into the past. Indeed, the term "transition" has clearly moved (or pardon the pun - "transitioned") from politics and international relations into gender studies ${ }^{2}$, and seismic alterations in global power-balances have - after Dipesh Chakrabarty - quite successfully "provincialized" the Cold War division into a regional dispute within today's Global North. ${ }^{3}$ If only for historical accuracy's sake, we need to recall how, from both a historical and a sociological standpoint, the conditions for cultural production under direct state management differ from those where the state does not view aesthetic divergence as an immediate assault on its authority.

To examine this moment of transitionality, I have selected, somewhat anomalously, not a publication but a physical location: the building located in Prague at the address Bolzanova 7, which immediately after the collapse of the Communist regime in Czechoslovakia served as the central location for the formerly samiz-

1 Strictly speaking, the cultural form of the "estrada" was restricted to the USSR, though the use of the term as a pejorative categorisation for official popular performance in other state-socialist countries was somewhat common in unofficial circles.

2 Note the recent work of BRUBAKER, Rogers. Trans: Gender and Race in an Age of Unsettled Identities. Princeton : Princeton University Press, 2016. It is indeed symptomatic that Brubaker's research in a previous era addressed questions of nationalism and national identity, most notably BRUBAKER, Rogers. Nationalism Reframed. Nationhood and the National Question in the New Europe. Cambridge : Cambridge University Press, 1996.

3 CHAKRABARTY, Dipesh. Provincializing Europe: Postcolonial Thought and Historical Difference. Princeton : Princeton University Press, 2000. 
dat, now legal independent press. For several months in 1990, Bolzanova 7 was the literal centre of autonomous publication in the Czech language (not counting, of course, the still-active exile press). Alongside this undeniable historical significance, though, the location of Bolzanova 7 is not merely emblematic but actively instructive, drawing attention to the essentially spatial dimensions of publishing activity, both linguistic and physical.

In linguistic terms, every publication is limited and defined by its language; concomitantly, the circulation range of a periodical - whether national newspaper or handmade fanzine - is itself a definition of its group of readers. Classically, Benedict Anderson noted the relation between the periodical and the emergence of collective awareness, expanding language to the wider territory of nation. ${ }^{4}$ However, among the scholars of nationalism it may be Ernest Gellner who has hitherto provided the most trenchant depiction of the processes of collective self-reification inherent in the national configuration of the "smaller" linguistic communities, with a special eye towardspost-Habsburg Europe.Gellner's paradigm case of "Ruritania" is, invariably, one of the severe difficulties of harmoniously mapping language onto geography; its result, as he noted with characteristic irony, has most often been the brutal reality of physical displacement: the ethnographic map that "resembles not Kokoschka, but, say, Modigliani [...] generally plain where one begins and another ends, and there is little if any ambiguity or overlap." ${ }^{\prime 5}$

To work in scholarship within the Modigliani-landscape of the Ruritanias, in essence, is to have methodological nationalism forced upon us. And it is hard to avoid the impression, when examining Czechoslovakia's post-1968 "normalization", that the artistic analogy might less match Modigliani than Mark Rothko in the massive social homogenisation imposed by thoroughgoing, unreformed state control. Nonetheless, Gellner's predominantly linguistic understanding of " $\mathrm{Ru}$ ritanian" nationalism needs to be supplemented with a more finely calibrated spatial awareness: the crucial role of differences of physical size and scale, and the spatialities of post-Habsburg national entities, including (though not limited to) the relation between urban centres and rural peripheries. Specifically, the idea of the capitol city of the small nation-state as the centre for language production and, in Anderson's term, "print-capitalism" ${ }^{\prime}$ should be examined more thoroughly and with greater rigour than the standard cliches of journalistic accounts or even participant testimony that, all too often, tends to be interpreted as mere personality-driven gossip. Against this alternative, I would like to propose a methodological optic that balances the individual accounts of the specific historic moment - predominantly oral or media interviews - against an analysis grounded in the ample corpus of theories of nationalism and national language-communities, yet with an awareness of the complexity of their division, as per $20^{\text {th }}$-century Europe, within the concrete, often devastatingly real physical spaces of national borders, exile-writing enclaves, or indeed city plans or capitol-periphery social divisions.

4 ANDERSON, Benedict. Imagined Communities. Reflections on the Origin and Spread of Nationalism. London : Verso, 1990, pp. 34-36.

5 GELLNER, Ernest. Nations and Nationalism. Ithaca : Cornell University Press, 1983, pp. 139-140.

6 ANDERSON 1990. 
Within this framework of language as a predominantly spatial entity, I aim to argue that the end of the system that - both politically and economically - made samizdat a forced exigency implied a wide-ranging social shift in which the integration of the former opposition into the new social order was a natural, indeed near-inevitable outcome. And conversely, that the connection between samizdat, even of a conventionally "subcultural" orientation, and the rise of the paper zines of the 1990s should, at least within the Czech-language space, be viewed as tenuous at best.

The story of Bolzanova 7 is relatively simple, yet highly revelatory. Essentially, this unoccupied former office building for Czechoslovak Rail was offered by the Czechoslovak state to an organisation known as the Independent Press Centre (Nezávislé tiskové středisko - NTS). This group of Prague-based samizdat publishers, closely linked to the central dissident base of Charter 77 (if not, indeed, actual signatories to this declaration), was formed literally within hours of the police attack on student demonstrators on 17 . November 1989, with editorial space offered in the Galerie u Řečických, at the address Vodičkova 10. The precise course of events is, understandably, somewhat uncertain, based on differing recollections among the various participants ${ }^{7}$; what is of greater importance for the present considerations is the extreme rapidity of the response from Czech samizdat and the striking cohesiveness of its participants once events came to a head. The NTS took as its mission the provision of information directly to international journalists and press agencies, avoiding the still largely compliant state media such as the Czech News Agency (Česká tisková kancelář - ČTK). By 1990, however, more or less in $\mathrm{March}^{8}$, not only had the emphasis shifted towards creating a new, free and legal print media for the new conditions, but the organisation had far outgrown the gallery space. One floor above the Czechoslovak-Soviet Friendship Society offices ${ }^{9}$, a semi-permanent office space was created for the news agency Informační servis (Information Service) - soon to become the newsweekly Respekt - alongside the editorships of several other periodicals, both samizdat publications now unexpectedly thrust into legality as well as entirely new titles. Some of them, like the originally underground cultural journal Revolver Revue, managed to survive up to the present as highly prestigious institutions; others, like the university newspaper Studentské listy or the music journal Konzerva/Na hudbu ${ }^{10}$ are hardly remembered today. However, one of the publications should be of particular interest,

7 To cite but two examples: PETRÁČEK, Zbyněk. Zprávy a chaos U Řečických. In Lidové noviny, 14. November 2009, https://www.lidovky.cz/noviny/zpravy-a-chaos-u-recickych.A091114_000118_ln_noviny_sko, or POSPÍCHAL, Petr. Vzpomínky na revoluce: 20. listopad. In Deník Referendum, http://denikreferendum. cz/clanek/19201-vzpominky-na-revoluci-20-listopad. Perhaps the most extensive descriptions, with ample pictorial material, have been provided by two of the major publications to emerge from the NTS: the special issue of the cultural quarterly Revolver Revue HOŘJŠ́, Tamara (ed.) 15 let Revolver Revue. Praha : Edice Revolver Revue, 2001, specifically pp. XXX, or BROLÍK, Tomáš. Týdeník Respekt: rok jedna. In Respekt, 23. November 2014, https://www.respekt.cz/tydenik/2014/48/rok-jedna or https://www. respekt.cz/25-let-respektu/ivan-lamper-nebyt-toho-taxikare-respekt-by-nevznikl.

8 Nezávislé tiskové středisko was, however, only registered officially as a "cooperative" (družstvo) on 27. July of the same year, according to the official documentation available at https://rejstrik.penize. cz/00550604-nezavisle-tiskove-stredisko-v-likvidaci.

9 BROLÍK 2014.

10 Literally Can for Music. Twelve issues were published until 1996, according to the holdings of the Czech National Library; the title was registered with the Ministry of Culture until 2003: https://www.mkcr.cz/ databaze-periodickeho-tisku-pro-verejnost-978.html?do[loadP]=1\&item.id=662 
since it perhaps corresponds best to the idea of the amateur-countercultural ethos of the fanzine: the former samizdat publication Vokno. ${ }^{11}$

Vokno was at this time hardly a new title: it dated back to 1979 , when the first handmade issues began to circulate among counterculturally-minded youth connected to the Czech illegal rock scene in the wake of the famous trial of the Plastic People of the Universe. Moreover, even its genre as a periodical set it apart from the better-known part of Czech samizdat in the 1970s, which tended to consist of manuscripts by authors of a certain pre-1968 standing: poets (Jaroslav Seifert), novelists (Ivan Klíma), philosophers (Jan Patočka) or historians. And for a third, its circles of distribution and production lay at a notable remove from Prague intellectuals, ranging largely among the hippie-influenced working-class young in provincial industrial towns. Vokno's geographic base was situated in the strange social laboratory of the Czech Sudetenland, ${ }^{12}$ most notably in the various communal-living experiments in decrepit German farmhouses. ${ }^{13}$

To a large extent, Vokno represented the printed (typed) voice of the state-defined category of "defective youth" (závadná mládež) caught up against their will in the state-socialist machinery: long-haired working-class quasi-dropouts, choosing unskilled employment and (whenever possible) avoiding military service, favouring illegal rock concerts over the doubtful attractions of Socialist Youth Union activities. ${ }^{14}$ And not surprisingly, it was attacked far more harshly by the state's judicial machinery. Its main editors and producers - František Stárek Čuňas, Ivan Martin Jirous, Michal Hýbek, Milan Frič - were arrested following a long surveillance campaign by the Czechoslovak political police (Státní bezpečnost - StB), under the designation Akce Satan, which in the words of its official evaluation planned "the paralysing of enemy activities of leading organisers from the ranks of hippies, underground and signers of $\mathrm{CH}-77$ [Charter 77] in the North Bohemia region and Czechoslovakia".15 After their conviction in May 1982 on charges of "hooliganism" and "disturbing the peace", along with a false marijuana accusation, all four were likewise given significant prison sentences. ${ }^{16}$ Yet Vokno was not an explicitly political publication, at least in the sense of presenting a concerted

11 All the samizdat issues of Vokno are accessible online at https://www.vons.cz/vokno.

12 Note e.g. SPURNÝ, Matěj. Most do budoucnosti: Laboratoř socialistické modernity na severu Čech. Prague : Karolinum, 2016, or for an English-language treatment GLASSHEIM, Eagle. Cleansing the Czechoslovak Borderlands: Migration, Environment and Health in the Former Sudetenland. Pittsburgh : University of Pittsburgh Press, 2016.

13 A history - admittedly only partial - of this phenomenon is found in STÁREK, František Čuňas - KOSTÚR, Jiří. Baráky. Souostroví svobody. Prague : Pulchra, 2011.

14 The Socialist Youth Union (Socialistický svaz mládeže), active from 1970 until 1989, formed the primary implement of the Czechoslovak Communist Party in the formation and shaping of youth activity during the post-1968 "normalisation" years, including the power to approve or ban music groups for public performance. Note in particular KUDRNA, Ladislav - STÁREK, František Čuňas. Kapela. Pozadí akce, která stvorila Chartu 77. Prague : Academia - Institute for the Study of Totalitarian Regimes, 2017, esp. pp. 6372, for a discussion of state-approved youth culture in Czechoslovakia in the early 1970s.

15 The wording of the report "Vyhodnocení prováděcího plánu na rok 1982 Státní bezpečnosti Ústí nad Labem z 1. listopadu 1982", cited in DENČEVA, Ivana. Underground jako politický fenomén. Diploma project. Prague : Department of Central European Studies, Faculty of Arts, Charles University, 2013, p. 118.

16 Descriptions of the Vokno trial are available in the extensive biography of ŠVEHLA, Marek. Magor a jeho doba. Prague : Torst, 2017, p. 431 and following; discussion of the preceding secret-police campaign and its effects on the cultural underground is provided (in part by another participant, i.e. Stárek himself) in KUDRNA - STÁREK 2017, pp. 160-203. The standpoint of a third participant is provided in BERNARD, Jan. Filmař disentu Michal Hýbek. In dok.revue, 2019, No. 4, https://www.dokrevue.cz/clanky/filmardizentu-michal-hybek, excerpt from forthcoming publication from Nakladatelství AMU, 2020. 
opposition to the regime. While it did not omit the unavoidable clashes with the state repressive forces (e.g. issue 8, which printed Stárek's courtroom appeal as well as the official judgment of the magazine's literary qualities from Dr. Vítězslav Rzounek of Charles University), it focused on providing its reader-network with information on international cultural goods under official embargo - above all, music - or the actual products of its network (poems and stories by various participants, reviews of underground bands).

In many respects, then, Vokno significantly resembled the zines of the decade to come: its stress on immediate personal testifying, its anchoring in musical subcultures, its gritty handmade aesthetic, its deliberate embrace of the socially autonomous sphere of its recipients. And yet these traits are offset by no less significant differences - lying less within the textual and physical form of the periodical itself than within its broader social ramifications and its actual role among opposition-minded youth in normalization-era Czechoslovakia. In other words, a certain correspondence of the physical object (the handmade periodical) in varying historical and social settings need not necessarily imply that the actual pragmatics of the creation and circulation of the similar objects are indeed similar. Semiotic references on a cultural level, in short, may often obscure the necessity of "sociologising" the culture behind both sign and signifier, let alone the conditions for the basic material emergence of one and the free exercising of the other.

Chief among these aspects, perhaps even the crucial deciding factor, is the story of Vokno under conditions of free and legal publication - the years in Bolzanova 7 up until the journal's dissolution five years later. Unlike its editorial neighbours Respekt and Revolver Revue, which are major journalistic and cultural institutions even today, Vokno not only failed to survive the turbulence of the 1990s but had even, at the point of its spatial institutionalisation, moved far from its beginnings. The primary spiritus agens of samizdat Vokno, and the veteran of several years' imprisonment for this contribution, František Čuňas Stárek, found a radically different field of activity immediately after the old regime's fall: joining the newly established Office for the Protection of the Constitution and Democracy (Úřad pro ochranu ústavy a demokracie) of the federal Interior Ministry as of its founding on 16. February $1990,{ }^{17}$ essentially the post-Communist intelligence service, and remaining in his post up through the establishment of the current Czech intelligence agency (Bezpečnostní informační služba - BIS) until resigning in 2007. The two main contributors to Vokno, Miroslav Vodrážka and Lubomír Drozd (better-known by his more frequent pseudonym Blumfeld SM), during this period focused far more intensively on presenting international - i.e. Anglo-American - cultural information in Czech translation than on offering a forum for domestic self-expression. Even more tellingly, the informational supplement to Vokno, entitled Voknoviny ${ }^{18}$, under the direction of Jakub Polák, by 1991 became the expli-

17 Historie vzniku BIS, https://www.bis.cz/historie/.

18 It should be noted, however, that Voknoviny was revived by Čuňas Stárek as an informational bulletin for underground and proto-underground music and cultural events after his departure from BIS. See ŠELIGA, Vojtěch. Současná undergroundová subkultura a Voknoviny. MA thesis. Prague : Charles University Faculty of Social Sciences, 2018. 
citly political left-anarchist A-Kontra, at the time among the strongest critical forums within Czech publishing as a whole - underscoring (if such were necessary) the rapid divergences of opinion among ex-dissidents in the new order.

By 1994, Vokno had sufficiently ensconced itself in public awareness as to become an easily appreciable satirical reference from popular novelist Michal Viewegh, mentioned as a fashion-attribute of Prague's gilded pseudo-bohemian youth in his novel Bringing Up Girls in Bohemia. ${ }^{19}$ One year later, its final issue, no. 30, appeared, while two of the professional graphic designers, Klára Kvízová and Petr Krejzek, soon shifted to the journal often regarded as Vokno's successor, the cyberpunkinfluenced Živel. ${ }^{20}$ Of course, the high production values of Živel and its notable distance from both the aesthetics and the stance of the old underground - Krejzek himself preferred to describe the new journal as "overground" ${ }^{21}$ - show clearly the trajectory of professionalisation and convergence with the rising market economy. The suddenness of the establishment of official status, though, along with the spatial and personal links to the new order, only provokes a question that perhaps lay in the background from the outset: Was samizdat always moving towards the resumption of "normality", to forming the new establishment once the normalisation-era gerontocracy finally left the scene? Or in another formulation - and one that can be generalised further to include other areas of post-1989 life - was it essentially a shadow establishment, a conservative element hoping for its correct, "normal" institutionalisation?

Obviously, the assumption contained in these rhetorical questions regards samizdat as an essentially conservative force, yearning for official legality, or at most a mere exigency of a situation regarded as "abnormal". And a further assumption is that samizdat production could be subsumed into a unified, organised, unequivocally political opposition - which is definitely an overstatement even within pre-1989 Czechoslovakia, and even taking into account the high degree of personal concentration of dissent into relatively restricted networks (Charter 77, the early underground associated with Vokno, the Prague cultural underground associated with Revolver Revue as prominent focal points). The chief error in these assumptions, in my own view, is the tendency to reify samizdat into a system of production, where the printed object (whether by typescript, offset or even conventional press) is the final aim. Samizdat should correctly be viewed less from the librarian's perspective than the network analyst's; ${ }^{22}$ the material object - even for all the difficulties of its physical creation - invariably bore less importance than the conditions of its circulation among the readers, who very often were its further (re)producers within the broader distribution network.

19 VIEWEGH, Michal. Výchova dívekv Čechách. Prague : Český spisovatel, 1994; English translation TURNER, Gerald. Bringing Up Girls in Bohemia. London : Readers International, 1997.

20 Literally "element". The most extensive discussion of Živel in scholarly literature to date has been KEJLOVÁ, Sabine. Časopis Živel a alternativní kulturní scéna 2009-2012. BA thesis. Prague : Charles University Faculty of Social Sciences, 2014, pp. 11-12.

21 According to Živel's co-founder: ADAMOVIČ, Ivan. Zakládání kyberkultury v Čechách. In Nový Prostor, 2018, No. 515, http://novyprostor.cz/clanky/515/zakladani-kyberkultury-v-cechach.

22 This argument is the central thesis of THARP, Martin. Šest aktérů odloučení: K teoretickému konceptu opozičních sítí a policejních zásahů. In KUDRNA, Ladislav (ed.) Od mániček $k$ undergroundu. Prague : Ústav pro studium totalitních režímů 2019, p. 148-161. 
Viewing this paradigm, in turn, from a slightly different angle, the spatiality of samizdat formed its own map - in a somewhat $20^{\text {th }}$-century term, we could call it a "countermap" - of interpersonal connections involved in the production/ consumption/reproduction linkages: a map almost invariably kept invisible (for reasons too obvious to bear description) but nonetheless highly resilient in its reliance on "who knows whom". It is a spatialising of openness (the "free" public arena of the reader/author/typist community) that is forced into a largely unwanted enclosure, simply to ensure safety from the political police. Indeed, the wider trajectory of Czech samizdat from the later 1970s onward tended strongly towards the expansion of the network from that of immediate personal friendships into a broader, increasingly impersonal ${ }^{23}$ proto-civil society. Between Vokno and Revolver Revue, ${ }^{24}$ as underscored by many conversations with former participants in Czech underground networks, there emerged not only a greater level of technological sophistication, possible only through strategic personal connections with trained printing experts ${ }^{25}$, but even more crucially the awareness that such "mainstreaming", as it were, was vital to the formulation of sufficient interpersonal space as the medium for true intellectual freedom. Only in a civil society - understood not in any sense as a normative label of approval but as the intellectual understanding forged in the late- $20^{\text {th }}$-century reaction to Europe's totalitarian legacy - can there be the distance for independence in general, and indeed for independent thought or independent cultural production.

The de-materialising aspect of samizdat production, as paradoxical as it might sound, is nonetheless understandable when considering the material conditions of a fully state-controlled economy. ${ }^{26}$ In this sense, it is worth recalling an often overlooked yet highly insightful critique emerging out of ex-Marxist dissidence - in this case the Budapest School - that addressed the command economy directly: the thesis of the "dictatorship over needs" proposed in the 1980s by Ferenc Fehér, Ágnes Heller and György Márkus. ${ }^{27}$ My brief and inevitably crude treatment does little justice to the sophistication of this dissident-Marxist critique of "really existing socialism", but for the present purposes one central point should be raised: for Fehér, Heller and Márkus, the shortages and restrictions

23 Note, for instance, the extensive use of nicknames in underground circles - often to the extent that longstanding underground participants never even knew the "official" names of relatively close friends. While this practice bears resemblance to the use of nicknames in other unofficial Czech subcultures (e.g. the "tramping" culture or unofficial/illegal Scouting organisations), its strict application among core members of underground networks may have further ramifications - possibly a formulation of a protocivil society between familial networks and the atomised state sphere. I have discussed this aspect in somewhat greater detail in THARP, Martin. Six Agents of Separation. Towards a Theoretical Concept for Oppositional Networks and Police Intervention, in process.

24 For several of its still-illegal issues, Revolver Revue bore the (English) subtitle "off ghetto magazine". A more extensive description was offered in a post-1989 address by Jáchym Topol originally delivered in English in the US. TOPOL, Jáchym. Contribution to a Closer Understanding of the Last Samizdat Generation. In MACHOVEC, Martin (ed.) Views from the Inside. Czech Underground Literature and Culture 1948 - 1989. Prague : Charles University-Karolinum Press, 2018.

25 See HOŘEJSII 2001.

26 It is worth remembering that socialist Czechoslovakia had a far higher degree of state control over economic activities than many other of its Warsaw Pact neighbours: not only in the massive collectivisation of agriculture but equally in the absence of private shops (e.g. Hungary) or even private activity in skilled crafts (GDR).

27 FEHÉR, Ferenc - HELLER, Ágnes - MÁRKUS, György. Dictatorship over Needs: An Analysis of Soviet Societies. Oxford : Blackwell, 1986. 
of the command economy were less of a bug than a necessary feature, related to the (highly un-Marxist) normative judgments of the state in its resource allocation. Creating a samizdat publication meant defying not only the censors of written content, but even the material strictures of assembling enough paper, carbon sheets, typewriter ribbons, or later printer ink, simply to create the physical medium of samizdat. ${ }^{28}$ Totalitarianism in normalisation-era Czechoslovakia, in short, should not be reduced merely to the use of police force to impose Great Generation taste, however important it is to keep this fact in collective memory both within and without the nation's borders. The extent to which the command economy served as a no less effective instrument of social control has yet to receive its due within Czech historiography, let alone in investigating the area of cultural-semiotic resistance specifically.

A secondary factor within the "dictatorship over needs" - also addressed by the work's authors - was the emergence of a kind of Marxist commodity fetishism, again in sharp contradiction to the regime's declared ideology. Increasingly, scholarship addressing the semiotic-aesthetic aspects of socialistAlltagsgeschichte has focused on the conditions of material uniformity and the subsequent fetishization both of imported goods and (more to the current point) of the "Socialist Biedermeier" of domestic art or craft-objects. ${ }^{29}$ Samizdat, by contrast, was a network where the consumer-producer divide was by necessity deliberately blurred, and where the "object" was never intended for possession or contemplation, but instead recirculation and active duplication. Never was there any deliberate stress placed on the production conditions as a guarantee of authenticity or of aesthetic force: no adherence to typescript when, for instance, offset printing suddenly appeared as a realistic possibility. Hence it was no surprise that the publication as a deindividuated - in Walter Benjamin's sense, entirely aura-free ${ }^{30}$ - industrial product was grasped with such avidity once it became a feasible and legal alternative, as in the offices at Bolzanova 7. The smooth fluidity of periodical circulation, with professional print technology and the full logistical support of post office and retail sales, was anything but a betrayal, a sell-out: instead, it was the necessary final point of ensuring a place within civil society where previously it had required such incredible risk and effort to create something even approximating such a "civil" order in the first place.

And a further aspect of the process of creating a genuine public space is itself mirrored in the spatial relations of the Bolzanova 7 offices. Here, we return to spatiality but not in the integrative sense of the post-Habsburg/Ruritanian capitol city

28 Martin Machovec, who has studied Czech samizdat from the unique standpoint of both participant and scholar, has drawn attention to this often-overlooked dimension of samizdat. "I, for one, tend to agree with opinions, suggesting that the criterion may not be so much of a purely political, but more of an economic character, at least as far as the totality of Stalinist, or neo-Stalinist type is concerned (but probably of a fascist type as well)." MACHOVEC, Martin. The Types and Function of Samizdat Publications in Czechoslovakia, 1948 - 1989. In Poetics Today, 2009, Vol. 30, No. 1, pp. 1-26.

29 The crucial discussion of this cultural atmosphere in normalisation-era Czechoslovakia is ČINÁTL, Kamil. Časy normalizace. In BÍLEK, Petr A. - ČINÁTLOVÁ, Blanka (eds.) Tesilová kavalérie. Popkulturní obrazy normalizace. Př́íbram : Pistorius \& Olšanská, 2010, pp. 166-187, esp. p. 178.

30 BENJAMIN, Walter. Das Kunstwerk im Zeitalter seiner mechanischer Reproduzierbarkeit, originally: L'œuvre d'art à l'époque de sa reproduction mécanisée. In Zeitschrift für Sozialforschung, 1936,Vol. 5, No. 1, p. 40-67. 
- instead, the dislocation of a distinct, professional editorial space away from the forced dissolution of production into daily life that samizdat production implied. An editorial office distinct from home is, once again, a semi-public space, an interior where efforts towards the widest of public spheres are concentrated. Samizdat, contrastingly, had to be produced in a domestic space: the flat or the weekend cottage, or occasionally the farmhouse of an underground commune; and no less crucial was the private-within-the-private, i.e. the secret chamber or attic where presses, typewriters or finished copies could be hidden in the event of a police raid. ${ }^{31}$ The moment of 1990, when an open society was being constructed literally from minute to minute, implied less of a physical "incorporation" of the new ex-dissident cultural elite than the assumption of professional methods and the re-valorization of the long-discredited public space. As important as access to printing technologies and materials was the necessary separation of the professional from the private, the vital "room of one's own" in which creative participation can emerge.

In a deliberately crude yet revelatory analogy, the samizdat vs. fanzine split of the early 1990s could be matched to a longstanding and deeply influential (even if somewhat problematic) division within worldwide social thought. Legalised, legitimated and indeed newly assimilated samizdat now expressed a desire for the distance and differentiation of a liberal, open-society Gesellschaft, including integration into the capitalist marketplace as a vital, indeed necessary factor. Post-1989 zines, contrastingly, could form a yearning for the strongly communitarian ties of Gemeinschaft - regardless of their geographic production point on either side of the dissolved Iron Curtain - as the close community of readership circulation forming a safe haven of kindred spirits in the anomic whirl of free-market triumphalism. Vokno, with its "Western countercultural" orientation placing it in uncertain balance between its guiding influences of the dual "Western" and "countercultural" stances in the agonistic moment of Communism's collapse, understandably found itself faced by its own transitional dilemma. Even amid the endlessly proclaimed optimism, the awareness remains that transitionality was merciless in its elimination of anything more ambiguous than these new Modigliani-colourfields of sharply defined ideological stances.

Vokno's Bolzanova 7 neighbours like Respekt or Revolver Revue successfully "transitioned" into full professionality and ever-increasing production values; the periodical as anodyne industrial product: Vokno itself occupied too much of a liminal state to do so. While of course personal factors, i.e. the succession of individual editors and authors, had their own part in Vokno's fate, it is tempting to ascribe its tortuous course through the early 1990s to a kind of inevitability. Not, of course, a Marxist-teleological one, but one of random contingency, a necessity of the immediate historical situation: the startling, sudden outbreak of an open

31 Tellingly, one participant in Czech samizdat, author and translator Jindřich Pokorný, refused - in an interview conducted a full decade after 1989 - to state where precisely his samizdat hiding-place was: "Mr. Gruntorád recommends that you don't say these things. You never really know." See: POKORNÝ, Jindřich. Kádrový posudek si každý napsal sám (interview with Adam Drda and Viktor Karlík). In Revolver Revue, 1999, No. 39, pp. 311-333, reprinted in RR Rozhovory. Praha : Revolver Revue, 2016, p. 433. Such reluctance, though, was rare in my own research among Vokno's participants: several respondents asked if I would be interested in photographing their reproduction equipment and their hiding-places. 
society, where the differentiation of the semi-enclosed/semi-open network no longer needed to be guarded with such excruciating care but instead now became the broadest principle of social organisation. Now, ironically, the space of the entire Czech nation could become what Vokno had, on such a modest scale, hoped to achieve for its isolated participants.

The ending of both political and - no less crucially - economic restrictions on print-material production within transition-era Czechoslovakia had, as one of its main results, an abrupt shift in the condition of the printed Czech language across the board. The free spatiality on the mental, interpersonal level of samizdat had moved, indeed been rapidly transplanted, fully and legitimately, into the physical realm. Not only the immediate factors of the individual psychology of key actors and the dynamism of events at the start of the 1990s, but more significantly the internal dynamics of Czech dissent, simultaneously aesthetic and political, drove pre-1989 samizdat either into a mainstream role or into the fatal dilemma faced by Vokno as the decade continued. With a (relatively) open print-market intact, the conditions were now ready for secondary communities to emerge, among them the new subcultural fanzines of all possible orientations - including the skinhead or football-hooligan cultures actively hostile to the liberalism of indifference and eager to follow the narrowest calls for belonging. Yet while not wishing to dismiss the potential dangers of illiberal print-communities, it is nonetheless worth stressing that any such restricted-circulation language production in conditions outside of European state-socialism remains significantly different, if not occasionally in appearance, in ambitions and wider social ramifications from pre-1989 samizdat.

Cite:

Tharp, Martin. Space, Paper, Transition/ality at Bolzanova 7. The Dissolution of the Czech Samizdat Scene and the Growth of Zine Culture in the 1990s. In Forum Historiae, 2020, Vol. 14, No. 2, s. 93-103. ISSN 1337-6861. DOI: https://doi.org/10.31577/forhist.2020.14.2.6

Martin Tharp

Department of Historical Sociology

Faculty of Humanistic Studies

Charles University in Prague

Pátkova 2137/5

18200 Praha 8 - Libeň

Česká republika

E-mail: mtharp@seznam.cz 